\title{
1 A new nektaspid euarthropod from the Lower Ordovician of Morocco
}

2

3

4

5

$6 \quad{ }^{1}$ Institute of Earth Sciences, University of Lausanne, Géopolis, CH-1015 Lausanne, Switzerland

7 2The Czech Academy of Sciences, Institute of Geology, Rozvojová 269, 16500 Prague 6, Czech

8 Republic

9 Institute of Geology and Palaeontology, Faculty of Science, Charles University, Albertov 6,

10 Prague, 12843, Czech Republic

$11 *$ francesc.perezperis@unil.ch

\author{
Orla G. Bath Enright ${ }^{1}$ and Allison C. Daley ${ }^{1}$
}

\section{Abstract}

14 Nektaspids are Paleozoic non-biomineralised euarthropods that were at the peak of their diversity

15 in the Cambrian period. Post-Cambrian nektaspids are a low diversity group with only a few

16 species described so far. Here we describe Tariccoia tazagurtensis, a new species of small

17 bodied nektaspid from the Lower Ordovician Fezouata Shale of Morocco. The new species

18 differs from the type (and only other known) species from the Ordovician of Sardinia (Italy),

19 Tariccoia arrusensis, in possessing more pointed genal angles, a cephalon with marginal rim, a

20 pygidium with anterior margin curved forwards, a rounded posterior margin and longer and more

21 curved thoracic tergites. The two specimens of T. tazagurtensis sp. nov. show remains of 
22 digestive glands that are comparable to those seen in the Cambrian nektaspid Naraoia. The rare

23 occurrence of T. tazagurtensis sp. nov. in the Fezouata Shale and the distribution of other liwiids

24 suggest that these liwiids were originally minor members of open marine communities in the

25 Cambrian, and migrated into colder brackish or restricted seas in the Ordovician.

26 Keywords: Tariccoia; Nektaspida; Euarthropoda; Ordovician; Morocco; Fezouata Shale

27

28

29

30

31

32

33

34

35

36

37

38

39

40

41

42

43

\section{Introduction}

Nektaspida Raymond, 1920 is a clade of artiopod euarthropods that were major constituents of Cambrian marine ecosystems, especially during Epoch 2 (Dzik and Lendzion 1988, Hou and Bergström 1997, Budd 1999, Zhang et al. 2007, Paterson et al. 2010) and the Miaolingian (Whittington 1977, 1985, Mayers et al. 2019). Nektaspids, however, are only rarely found in the younger strata of the Ordovician (Hammann et al. 1990, Fortey and Theron 1994, Budil et al. 2003, Van Roy et al. 2010, Van Roy 2013, Van Roy et al. 2015a) and Silurian (Caron et al. 2004). Nektaspida is generally considered to contain three families: Naraoiidae, Liwiidae and Emucarididae (Paterson et al. 2010, Paterson et al. 2012, Legg et al. 2013, Mayers et al. 2019), and the genus Buenaspis (Lerosey-Aubril et al. 2017, Chen et al. 2019). In addition to these three families, recent phylogenetic analyses have suggested that Nektaspida may also include other artiopods not traditionally classified with this clade, such as Petalopleura, Saperion, Tegopelte (Mayers et al. 2019), Phytophylaspis, Panlongia, (Legg et al. 2013, Hou et al. 2018) and Campanamuta (Legg et al. 2013). Consequently, they have been central to discussions of the first appearance and expanding diversity of euarthropods, and of animals more broadly, during the radiations of the Cambrian Period (Budd et al. 2001, Marshall 2006, Daley et al. 2018). The 
44 possession of a non-biomineralised exoskeleton (Hammann et al. 1990, Edgecombe and 45 Ramsköld 1999), together with changes in their habitat preferences (e.g. Hammann et al. 1990), 46 could explain such scarcity in the fossil record after the Miaolingian, after which time soft tissue 47 preservation declines in abundance and quality (Brasier et al. 2011, Peters and Gaines 2012, 48 Gaines et al. 2012, Daley et al. 2018). Consequently, the diversity of nektaspids in post49 Cambrian ecosystems is low, but this seems likely to be a result of taphonomic bias, rather than 50 representing a true evolutionary absence.

51 Similar bias occurs in our knowledge about the morphology and anatomy of nektaspid soft-parts.

52 The detailed information regarding morphology of the appendages, ventral sternites and 53 digestive system is largely restricted to the Family Naraoiidae (Whittington 1977, Chen et al. 54 1997, Vannier and Chen 2002, Mayers et al. 2019, Zhai et al. 2019). In the family Emucarididae 55 only cephalic appendages have been described by Paterson et al. (2010b). In Liwiidae, a pair of 56 antennae were figured in Liwia plana (Lendzion, 1975) (see Dzik and Lendzion 1988), but the 57 data regarding post-antennal appendages are missing. This lack of morphological and anatomical 58 information hinders our understanding of the phylogeny and ecology of the Nektaspida and the 59 Artiopoda more broadly.

60 Herein Tariccoia tazagurtensis sp. nov., is described from the Lower Ordovician (Tremadocian)

61 Fezouata Shale Konservat-Lagerstätte of Morocco. This is the first species of Liwiidae (and of 62 Nektaspida) to be described from the Lower Ordovician. Tariccoia tazagurtensis sp. nov. shows 63 strong similarity with Tariccoia arrusensis Hammann et al., 1990 from the Middle or Upper 64 Ordovician of Sardinia (Italy). The first description of the anterior digestive glands in Liwiidae, 65 is also presented augmenting knowledge of soft parts in Nektaspida. Moreover, 
66 palaeogeographic distribution patterns and habitat preferences are evaluated in this euarthropod

67 group.

68

69

70

\section{Geological settings}

71 The Fezouata Shale is a sequence of Lower Ordovician strata geographically belonging to the

72 Anti-Atlas region of Morocco. North of Zagora, the Lower Ordovician is exposed in the Ternata

73 plain, forming the Outer Feijas Shale Group, Tremadocian to early Darriwilian (Choubert et al.

74 1947, Destombes et al. 1985). The Outer Feijas Shale Group unconformably overlies middle

75 Cambrian sandstones of the Tabanite group and underlies the First Bani Group (Middle

76 Ordovician; Destombes et al. 1985, Martin et al. 2015). The Outer Feijas Shale Group is

77 subdivided into the Lower Fezouata Shale formation, the Upper Fezouata Shale formation, the

78 Zini sandstone and quatzite formation and the Tachilla Shale formation (Destombes et al. 1985).

79 In the Zagora area, the boundary between the Lower and the Upper Fezouata formation is 80 unclear, with both formations grouped into a single, $850 \mathrm{~m}$ thick unit called the "Fezouata Shale"

81 (Martin et al. 2016). The Fezouata Shale contains the only known Konservat-Lagerstätte from

82 the Lower Ordovician providing a critical link between the evolutionary events of the Cambrian

83 Explosion and the Great Ordovician Biodiversification Event (Servais et al. 2010, Landing et al.

84 2018, Servais and Harper 2018). The Fezouata Shale is renowed for its exceptional preservation 85 of non-biomineralised body fossils and contains more than 160 different genera (Van Roy et al. 86 2010, Van Roy et al. 2015b, Van Roy et al. 2015a, Saleh et al. 2019). The exceptional 87 preservation occurs in two horizons (Martin et al. 2016, Lefebvre et al. 2018), the lower interval 
88 of which is about $70 \mathrm{~m}$ thick and situated $260-330 \mathrm{~m}$ above the Cambrian-Ordovician contact, 89 and the second of which is about $50 \mathrm{~m}$ thick and $570-620 \mathrm{~m}$ above the Cambrian-Ordovician 90 contact. The lower interval with exceptional preservation is situated mostly within the 91 Araenograptus murray Zone and lowermost parts of the Hunnegraptus copiosus Zone, which 92 both correspond to the late Tremadocian (Stage slice Tr3, see Gutiérrez-Marco and Martin 2016, 93 Lefebvre et al. 2018). This age is further corroborated by acritarchs and conodonts that also 94 support a latest Tremadocian age for this level (Lehnert et al. 2016, Nowak et al. 2016). The 95 upper interval with exceptional preservation most likely belongs to the ?Baltograptus jacksoni 96 Zone, which is of Floian age (Lefebvre et al. 2018).

97 The Fezouata Shale is generally composed of argillites with blue-green to yellow green sandy 98 mudstone and siltstones interbeds (Destombes et al. 1985). It is interpreted to have been 99 deposited around storm wave-base, in an open shallow marine environment (Martin et al. 2015), 100 ranging from proximal offshore to foreshore with a depth range from 50 to $150 \mathrm{~m}$ (Martin et al. 101 2015, Vaucher et al. 2016). The fluctuations of the water level are of low amplitude, but it is 102 possible to recognize the deepest depositional environment in the middle of the Fezouata Shale 103 (Martin et al. 2016).

\section{Material and Methods}

106 Two specimens assigned here to Tariccoia tazagurtensis sp. nov. were studied. Both specimens 107 are covered by iron oxides and/or hydroxides and preserved as compressions in shales. To 108 expose the whole individual, the parts were mechanically prepared with a Micro-Jack 4 equipped 109 with 4/16" chisel. Photographs were taken with a digital camera Olympus E-PL8 with associated 
110 Olympus M.Zuiko $30 \mathrm{~mm} \mathrm{f/3,5}$ macro lens. The lens was equipped with a polarizing filter to 111 reduce reflections, and a second polarizer on the light source created crossed polarization to 112 increase contrast. All specimens were photographed with low angle NW lighting, both dry and 113 immersed in ethanol (to increase contrast between rock and specimen). The images were 114 subsequently processed in Adobe Photoshop CC 19.0, to enrich brightness, contrast, shadows, 115 highlights and saturation. Line drawings were made directly from photographs using Adobe 116 Illustrator CC 22.0.1., like a digital camera lucida (Antcliffe and Brasier 2011).

\section{Systematic palaeontology}

Emended diagnosis. Family of Nektaspida with the following combination of characters: three to 124 four thoracic tergites that are narrower (tr.) than the cephalic shield; first one or two thoracic 125 tergites overlapped by cephalic shield; pygidium narrower than the cephalic shield, but of similar 126 length to the cephalic shield.

128 Discussion. Liwiidae was originally proposed as a family, although not erected formally (Dzik 129 and Lendzion 1988). They used the presence of free thoracic tergites to distinguish it from 130 Naraoiidae, which is characterized by the absence of articulating thoracic tergites. Fortey and 
131 Theron (1994) instead included the liwiid genera Maritimella Repina \& Okuneva, 1969, Liwia 132 Dzik \& Lendzion, 1988, Tariccoia Hammann et al., 1990, and Soomaspis Fortey \& Theron, 1994 133 in the family Naraoiidae. They considered the presence of three or four free thoracic segments a 134 plesiomorphic character of the group and not valid for designating a new family. Hou and 135 Bergström (1997) formally elevated Liwiidae to family level, but without providing a diagnosis. 136 They included the genera Liwia, Tariccoia and Soomaspis in the Liwiidae. Budd (1999) defined 137 family Liwiidae by having more than one axial articulation and added the genus Buenaspis 138 Budd, 1999. However, in recent phylogenetic analyses Buenaspis was always resolved either 139 outside the Liwiidae, but inside Nektaspida (Legg et al. 2013, Lerosey-Aubril et al. 2017, 140 Mayers et al. 2019, Chen et al. 2019), or even outside Nektaspida itself (Paterson et al. 2010, 141 Paterson et al. 2012). Recently, most analyses resolve Liwiidae as a monophyletic group that is 142 sister to Naraoiidae (Paterson et al. 2010, Paterson et al. 2012, Ortega-Hernández et al. 2013a, 143 Lerosey-Aubril et al. 2017, Chen et al. 2019) or sister to Emucarididae (Legg et al. 2013, Hou et 144 al. 2018). In the analysis of Mayers et al. (2019) liwiids were resolved within Naraoidae, which 145 led the authors to demote Liwiidae to the subfamily level and include it within the family 146 Naraoidae. We prefer to keep Liwiidae at the family level for two reasons: 1) the topology 147 presented by Mayers et al. (2019) is the only analysis with Liwiidae resolved inside Naraoiidae 148 in recent years; and 2) this topology also shows a low degree of nodal support in favour of the 149 position of Liwiidae within Naraoiidae.

150 
153 Type species. Tariccoia arrusensis Hammann et al., 1990; $100 \mathrm{~m} \mathrm{~N}$ of the mouth of the Roia

154 Srappas into the Riu Is Arrus, ca. $4 \mathrm{~km} \mathrm{SE} \mathrm{of} \mathrm{Fluminimaggiore} \mathrm{(Sardinia,} \mathrm{Italy);} \mathrm{Riu} \mathrm{is} \mathrm{Arrus}$

155 Member of the Monte Argentu Formation (Upper Ordovician, see Hammann and Leone 1997).

156

157 Emended diagnosis. A genus of Liwiidae with the following combination of characters: cephalic 158 shield sub-circular; four thoracic tergites with rounded lateral extremes; first one or two thoracic 159 tergites overlapped by posterior margin of cephalic shield; pygidium longer than wide, with a 160 long median keel and smooth (non-spinose) margin.

161

162 Remarks. The diagnosis of Tariccoia provided by Hammann et al. (1990) is now regarded as the 163 diagnosis of the type species Tariccoia arrusensis Hammann et al., 1990.

Discussion. Liwia differs from Tariccoia in its pointed tips of the thoracic tergites and sub-

166 trapezoidal pygidium with well-defined axial part and with marginal spines. Soomaspis differs

167 from Tariccoia by having only three thoracic tergites with articulating half-rings, an axial part 168 defined on the trunk, and by a sub-circular pygidium showing five pleural furrows.

Tariccoia tazagurtensis sp. nov. 
173 Zoobank no. Will be added.

174

175 Material, locality, horizon. Holotype (Fig. 1a-c): MGL 102155a (part) and MGL 102155b

176 (counterpart). Other material: MGL 103036a (part) and MGL 103036b (counterpart). Both

177 specimens come from an outcrop located in the Ternata plain, ca. $18 \mathrm{~km} \mathrm{NW}$ of the city of 178 Zagora (Morocco) and ca. $6 \mathrm{~km} \mathrm{NNE}$ of the village of Beni Zouli. The outcrop falls within the 179 lower exceptional preservation interval of the Fezouata Shale (Araneograptus murrayi Zone, 180 Tremadocian, Lower Ordovician). Material is stored in the collections of the Cantonal Museum 181 of Geology (Lausanne, Switzerland). Exact locality data curated with the specimens.

183 Etymology. In Tamazight language, Tazagurt $\left(\dagger_{\circ} \varkappa_{\circ} \mathbf{X}_{\circ}^{\circ} \mathrm{O}+\right.$ in Neo-Tifinagh script) is a name for 184 the city of Zagora near which the material was discovered. Tamazight is a language of the 185 Amazigh people, an ethnic group that is indigenous to north Africa and have large population in 186 the Anti-Atlas region of Morocco.

188 Diagnosis. A small (up to $8 \mathrm{~mm}$ long) species of Tariccoia having the following unique 189 combination of characters: cephalon with pointed genal angles and marginal rim; pygidium with 190 anterior margin curved forwards, a rounded posterior margin, and a medial keel that does not 191 reach posterior pygidial border. 
193 Description. The total exoskeletal length is $6.68 \mathrm{~mm}$ in specimen MGL 103036a and 7.24 $\mathrm{mm}$ in 194 specimen MGL 102155a. Cephalic shield is sub-circular in outline and its sagittal length ranges 195 between $3.04 \mathrm{~mm}$ in MGL 103036a and 3.39 $\mathrm{mm}$ in MGL 102155a, and transverse width 196 between $3.47 \mathrm{~mm}$ in MGL 103036a and 3.79 mm in MGL 102155a. The anterior and lateral 197 margins of the cephalic shield ('ce' in Fig. 1b, e) are rounded, and the posterior cephalic margin 198 is anteriorly curved. The cephalic shield reaches its maximum width near the mid-length. A 199 distinct anterior marginal cephalic rim ('rm' in Fig. 1b) is delineated by a sharp ridge ('rd' in 200 Fig. 1b). The length of the cephalic rim extends to about one fifth the cephalic shield, being 201 longest (sag.) in the medial part. The postero-lateral edges of the cephalic shield form distinct, 202 pointed genal angles ('ga' in Fig. 1b) with rounded tips. The dorsal surface of the cephalic shield 203 is without trilobation, facial sutures or visual organs. The holotype MGL 102155a (Fig. 1a-c) 204 shows raised finger-like structures ('dg' in Fig. 1b, see also Fig. 2a) that are connected medially 205 and located in the anterior half of the cephalic shield. In specimen MGL 103036a (Fig. 1d-e), the 206 surface of the cephalic shield preserves distinct, radially arranged, wrinkles ('dg' in Fig. 1e, see 207 also Fig. 2b).

208 The thorax is comparatively narrow (tr.), being approximately $70-80 \%$ of the width of cephalic 209 shield. It is composed of four thoracic tergites, but the anterior two (1st and 2nd) tergites ('T1' 210 and 'T2' in Fig. 1b, e) are overlapped by the posterior portion of the cephalic shield ('ce' in Fig. $2111 \mathrm{~b}, \mathrm{e})$, and consequently are not easily discernible in the holotype, but are clearly visible in MGL 212 103036a. The two posterior (3rd and 4th) thoracic tergites ('T3' and 'T4' in Fig. 1b, e) are 213 completely exposed (Fig. 1a-f). In dorsal view all thoracic tergites are curved backward and 214 slightly downwards abaxially. The thoracic tergites become slightly wider (tr.) and more curved 215 posteriorly, so the 4th tergite is the widest and is in its medial part strongly deflected forward. 
216 The first tergite seems to taper abaxially. No distinct axial lobe is visible in any of the tergites.

217 The lateral extremes of each tergite end in rounded tips. No articulating facets or articulating 218 half-rings are present in the thoracic tergites. The tergites seem to be articulated with each other 219 by a narrow flange (' $\mathrm{fl}$ ' in Fig. 1e) that is visible and runs along the anterior margin of the 3rd 220 and 4th tergites (Fig. 1d-f), but is probably also present in the 1 st and 2 nd.

221 Pygidium ('py' in Fig. 1b, e) is sub-oval in outline, elongated and measures $3.08 \mathrm{~mm}$ (MGL 222 103036a) and $3.18 \mathrm{~mm}$ (MGL 102155a) in sagittal length and $2.52 \mathrm{~mm}$ (MGL 103036a) and $2233.04 \mathrm{~mm}$ (MGL 102155a) in transverse width. Consequently, the pygidium is aproximately $25 \%$ 224 narrower than the cephalic shield, and is just slightly wider than the thorax. The anterior margin 225 of the pygidium is curved forward, exactly matching the posterior margin of the last thoracic 226 tergite. A narrow flange (' $\mathrm{fl}$ ' in Fig. 1e) runs along the anterior margin of the pygidium. The 227 posterior margin of the pygidium is rounded. The central part of the pygidium is slightly inflated 228 and slopes down abaxially and posteriorly. In its medial part, the pygidium carries a pronounced 229 median keel ('mk' in Fig. 1b, e), that is nearly as long as the entire pygidium but does not reach 230 its posterior margin.

232 Discussion. Tariccoia tazagurtensis sp. nov. resembles Tariccoia arrusensis from the Ordovician 233 of Sardinia (Hammann et al. 1990, Hammann and Leone 1997), in overall morphology of both 234 the cephalon and pygidium and in possessing four thoracic tergites with rounded lateral 235 extremes. The differences between these two species are (see also Fig. 3a, b for comparison): 1) 236 more pointed genal angles in T. tazagurtensis sp. nov.; 2) the cephalon with marginal rim in $T$. 237 tazagurtensis sp. nov.; 3) the pygidium in T. tazagurtensis sp. nov. has anterior margin curved 238 forwards and rounded posterior margin, while in $T$. arrusensis the anterior pygidial margin is 
239 nearly straight and the posterior margin is pointed; 4) the thoracic tergites are proportionally 240 longer (sag.) and more curved in T. tazagurtensis sp. nov.; 5) the median keel in T. tazagurtensis 241 sp. nov. never reaches the posterior pygidial margin, but it does in T. arrusensis; and 6) the 242 pygidium of $T$. tazagurtensis sp. nov. lacks the sharp lateral edges forming a ventral ridge seen in 243 T. arrusensis (sensu Hammann et al. 1990, text-fig. 4).

244 The sharp ridge that separates the marginal rim of the cephalon is one of the characters that 245 distinguishes $T$. tazagurtensis sp. nov. from T. arrusensis. This structure is only preserved well 246 in the holotype (MGL 102155, Fig. 1a, b). For this reason, it is not easy to interpret it 247 unambiguously. This structure could also be interpreted as an imprint of the cephalic doublure or 248 compaction related deformation of the cephalic margin.

249 The exact number of thoracic tergites in T. tazagurtensis sp. nov. is not easy to determine, 250 because the anterior ones are overlapped by the cephalic shield. Such an overlap in Tariccoia, 251 Liwia and Soomaspis was recognised by Edgecombe and Ramsköld (1999, character 9) and used 252 as one of the synapomorphies of Liwiinae (= Liwiidae in this paper). Contrary to Edgecombe and 253 Ramsköld (1999), we suggest that in Tariccoia the cephalic shield overlap the first and also the 254 second (at least partially) thoracic tergite. In all articulated specimens of $T$. arrusensis usually 255 two or at most three thoracic tergites are exposed, while specimens lacking the cephalic shield 256 always show four (Hammann et al. 1990, pl. 1-3; Hammann and Leone 1997, pl. 1, fig. 1-3). In 257 some articulated specimens, however, the anterior one or two tergites are imprinted onto the 258 posterior portion of the cephalic shield (Hammann et al. 1990, pl. 1, fig. 1, 2, 5). Similar 259 exoskeletal configuration was likely present also in T. tazagurtensis sp. nov. Specimen MGL 260 103036a (Fig. 1d-f) shows clearly two posterior tergites, and traces of two more under the 261 posterior part of the cephalic shield. Although, the slightly different shape of the 1st thoracic 
262 tergite (Fig. 1d) in T. tazagurtensis sp. nov. resembles an articulating half-ring, the interpretation 263 of it as a thoracic tergite is favoured for two main reasons. Firstly, it is too wide to be an 264 articulating half-ring, and secondly, it is quite similar to the shape of first thoracic tergite in $T$. 265 arrusensis (cf. Hammann et al. 1990, pl. 2, fig. 2a-b).

266 The articulation of individual thoracic tergites and of the pygidium was apparently facilitated by 267 a structure morphologically similar to a flange as is known in the pleural parts of numerous, 268 especially basal, trilobites (Whittington 1989, Geyer 1996, Ortega-Hernández et al. 2013b, 269 Esteve et al. 2013, Laibl et al. 2016). Such an articulation can be regarded as functionally simple, 270 as no other articulation structures are present (e.g. articulating half-rings, fulcrum, or articulating 271 facet, cf. for example with Bruton and Haas 1997). With such a simple articulation, it seems 272 unlikely that $T$. tazagurtensis sp. nov. was able to enroll, as the flange does not allow for rotation 273 movement of arched structures, such as the thoracic tergites of T. tazagurtensis sp. nov.

\section{Digestive system in Tariccoia tazagurtensis sp. nov.}

277 There is currently little understanding of the soft anatomy in the Liwiidae. So far, only a pair of 278 antennae were described for Liwia plana (Dzik and Lendzion 1988), but no other information of 279 the postantennal appendages, the digestive system, or the nervous system has been reported.

280 The holotype of T. tazagurtensis sp. nov. shows finger-like structures connected medially under 281 the anterior half of the cephalic shield (Fig. 2a). We interpret these structures as the proximal 282 parts of a pair of well-developed ramified digestive glands connected to an anterior part of the 283 digestive tract. Both their preservation and morphology strongly resemble such structures as seen 
284 in Naraoia spinosa Zhang and Hou, 1985 from Chengjiang (cf.Vannier and Chen 2002, fig. 2A, 285 B, Zhang et al. 2007, fig. 28, 29). The distal ramification of the digestive glands is not preserved 286 in the holotype, but the other specimen (MGL 103036a) shows numerous wrinkles, some of 287 which seem to bifurcate distally (Fig. 2b). These are likely not compression-related wrinkles, 288 which are usually concentric (cf. Hammann et al. 1990, Budd 1999, Caron et al. 2004) or 289 randomly orientated (Peng et al. 2012), as opposed to radial in MGL 103036a. These structures 290 therefore likely represent the distal parts of the ramified digestive glands. Digestive structures are 291 known from Megistaspis (Ekeraspis) hammondi Corbacho \& Vela, 2010 and other trilobites 292 from the Fezouata Shale (Gutiérrez-Marco et al. 2017; Van Roy et al. 2015a), showing that 293 preservation of gut features is possible at this locality. Preservation of internal soft tissues in 294 general is relatively rare in the Fezouata Shale compared to other BSTs such as the Burgess and 295 the Chengjiang Biota, and is usually only founds in the presence of a mineralized or sclerotized 296 external cuticle (Saleh et al. 2020), as is the case with trilobites and T. tazagurtensis respectively.

297 Within Nektaspida the digestive system is known only in Naraoiidae and up to now, two 298 different morphotypes have been recognized (Vannier and Chen 2002) - one with a long, 299 extensively ramified anterior pair of digestive glands, present in species of Naraoia Walcott, 3001912 and in Misszhouia canadensis Mayers et al., 2019 (see Vannier and Chen 2002, Mayers et 301 al. 2019) and one with only short digestive glands present in Misszhouia longicaudata Zhang and 302 Hou, 1985 (Vannier and Chen 2002). Given that the digestive system of T. tazagurtensis sp. nov. 303 resembles the ramified pattern seen in Naraoia and M. canadensis, we suggest that these 304 morphologies are homologous. Indeed, the majority of phylogenies would suggest a single origin 305 for the well-developed ramified digestive glands in both naraoids and liwiids (e.g. Paterson et al. 306 2010, Ortega-Hernández et al. 2013a, Lerosey-Aubril et al. 2017, Mayers et al. 2019). 


\section{Distribution and habitat preferences in liwiids}

310 The distribution of liwiids shows a different pattern than that of other nektaspids (Fig. 4). 311 Naraoiids have a comparatively wide distribution, being known from low latitudes of 312 Laurentia/Laurussia (Whittington 1977, Robison 1984, Caron et al. 2004, Schwimmer and 313 Montante 2007, Mayers et al. 2019, Lerosey-Aubril et al. 2020), South China (Hou and 314 Bergström 1997, Chen et al. 1997, Zhang et al. 2007, Peng et al. 2012, Fu et al. 2019) and 315 possibly also from high latitudes on the West Gondwana margin (Budil et al. 2003). Emucaridids 316 are restricted to low latitude areas of East Gondwana (Paterson et al. 2010) and South China 317 (Zhang et al. 2012). According to the results of Mayers et al. (2019) putative nektaspids 318 including petalopleurans indicate a broader distribution, equatorial in Laurentia (Whittington 319 1985, Budd 1999, 2011), South China (Hou and Bergström 1997) and Siberia (Ivantsov 1999), 320 with the exception of Xandarella mauretanica Ortega-Hernández et al., 2017 from West 321 Gondwana (Ortega-Hernández et al. 2017).

322 In the Cambrian, the only liwiids (sensu stricto, i.e. without genus Buenaspis) so far described 323 are Liwia convexa (Lendzion, 1975) and Liwia plana (see Lendzion 1975, Dzik and Lendzion 324 1988), both known from boreholes in NE Poland (Baltica, Fig. 4). An Atdabanian age for the 325 Liwia bearing beds has been inferred (Dzik and Lendzion 1988), which roughly corresponds to 326 the provisional Cambrian Stage 3 within the early Cambrian subdivision (Zhang et al. 2017), 327 making this older than the more famous and fossiliferous Early Cambrian Konservat328 Lagerstätten: the Sirius Passet and Chengjiang biotas (Zhang et al. 2001, Harper et al. 2019). 
329 After this early first appearance, liwiids are completely absent from the renowned low latitude 330 Konservat-Lagerstätten of the rest of the Cambrian, including Sirius Passet (Harper et al. 2019), 331 the Chengjiang Biota (Hou and Bergström 1997, Zhao et al. 2009), Emu Bay Shale (Paterson et 332 al. 2016), Burgess Shale (Dunne et al. 2008, Caron and Jackson 2008) and Weeks Formation 333 (Lerosey-Aubril et al. 2018). This suggests that during the Cambrian, liwiids were either 334 extremely rare, formed restricted populations, and/or preferred specific environmental conditions 335 that were not conductive for exceptional preservation.

336 Previously published Ordovician liwiids are only known from localities that represent atypical 337 marine conditions, where nektaspids are not commonly found. Soomaspis splendida Fortey \& 338 Theron, 1994 is known only from the Soom Shale Member of the Cedaberg Formation, South 339 Africa (Fortey and Theron 1994; Fig. 4), where the depositional environment is interpreted to be 340 brackish-to-marine setting, close to a retreating and downwasting ice front (Theron et al. 1990, 341 Aldridge et al. 1994). Tariccoia arrusensis occurs abundantly in the Riu Is Arrus Member of the 342 Monte Argentu Formation of SW Sardinia (Hammann et al. 1990; Hammann and Leone 1997) 343 that is considered to be largely deposited in terrestrial and marginal marine environments 344 (Oggiano et al. 1986, Hammann et al. 1990). Sedimentological, biostratinomical and 345 palaeontological data suggest that $T$. arrusensis inhabited a restricted marine oxygen deficient 346 (sheltered bay, lagoon) environment, populated mainly by this species and macroscopic algae 347 (Hammann et al. 1990; Hammann and Leone 1997).

348 Tariccoia tazagurtensis sp. nov. is the only Ordovician liwiid described from a typical open 349 marine deposits. Unlike the abundant T. arrusensis of the Monte Argentu Formation, $T$. 350 tazagurtensis sp. nov. is a very rare faunal component of the Fezouata Shale community. This 351 species is not even locally abundant as shown by its general absence from most of the excavated 
352 sites and from both the proximal and distal parts of the Fezouata Shale, despite extensive 353 collecting in these areas. Moreover, the available specimens of T. tazagurtensis sp. nov. are 354 complete and articulated. Considering their non-biomineralized exoskeleton and the presence of 355 digestive glands, these specimens likely represent carcasses. Interpretations of the 356 palaeoenvironmental settings of the Fezouata Shale (Martin et al. 2016) suggest that these fossils 357 experienced little or no transport before deposition. Therefore, it seems that $T$. tazagurtensis sp. 358 nov. was living in the environment in which it was found.

359 From a palaeogeographic point of view, all Ordovician liwiids were restricted to cold-water 360 settings (Fig. 4). Both T. tazagurtensis sp. nov. and T. arrusensis are known from very high 361 latitudes on the West Gondwana margin (cf. Scotese 2004, Torsvik and Cocks 2013a, 2013b), 362 close to the South Pole. Soomaspis splendida comes from an area that was located at around $36330^{\circ} \mathrm{S}$ in the Late Ordovician (Torsvik and Cocks 2013a, 2013b), apparently in cold water very 364 close to a retreating ice shield (Aldridge et al. 1994). Liwiids might thus have preferred cold 365 water conditions (at least during Ordovician), in contrast to naraoiids, emucaridids and other 366 nektaspids.

367 The stratigraphic distribution of liwiids suggest that they were originally components of open 368 marine communities (Liwia, T. tazagurtensis sp. nov.), but were apparently rare. By the Middle 369 and Upper Ordovician, some of their members had migrated to brackish marine environments $(S$. 370 splendida) or to restricted areas where they formed locally abundant populations (T. arrusensis).

\section{Summary}


374 1. A new species of a small nektaspid euarthropod - Tariccoia tazagurtensis sp. nov. - is 375 described from the Lower Ordovician (Tremadocian) Fezouata Shale Konservat376 Lagerstätte of Morocco. This species is characterized by a sub-circular cephalon with 377 pointed genal angles and with a marginal rim; a thorax consisting of four tergites, the $1^{\text {st }}$ 378 and $2^{\text {nd }}$ of which are overlapped by the cephalic shield; and by a pygidium with its 379 anterior margin curved forwards, a rounded posterior margin, and a long medial keel that 380 does not reach the posterior pygidial border.

381 2. Tariccoia tazagurtensis sp. nov. preserves remains of the anterior part of the digestive 382 tract, which is comparable to the ramified digestive glands seen in species of Naraoia and 383 Misszhouia canadiensis. This is the first description of the digestive system in Liwiidae.

384 3. From the distribution and abundance data of Liwiidae, it is likely that members of this 385 group preferred cold-water settings, in contrast to other nektaspids, and were members of 386 open marine communities during their early evolutionary history, but later migrated to 387 brackish or restricted environments.

389 Acknowledgements. We thank Peter Van Roy for careful reading earlier version of the 390 manuscript. We are graterful to Rudy Lerosey-Aubril and Gian Luigi Pillola for discussion 391 related to digestive system in euarthropods and to Tariccoia arrusensis, respectively. The 392 manuscript was greatly improved by referees comments from John Paterson and Javier Ortega 393 Hernández. This research was funded by the Swiss National Science Foundation, grant number 394 205321_179084 entitled "Arthropod Evolution during the Ordovician Radiation: Insights from 395 the Fezouata Biota" and awarded to A. Daley. L. Laibl is supported by the Grant Agency of the 
396 Czech Republic (GACR) project no. 18-14575S, by the institutional support RVO 67985831 of 397 the Institute of Geology of the Czech Academy of Sciences and by Center for Geosphere 398 Dynamics (UNCE/SCI/006). This paper is a contribution to the International Geoscience 399 Programme (IGCP) Project 653 - The onset of the Great Ordovician Biodiversification Event.

Conflict of interest. None.

\section{References}

Aldridge, R.J., Theron, J. and Gabbott, S. 1994. The Soom Shale: a unique Ordovician fossil horizon in South Africa. Geology Today 10 (6): 218-221.

Antcliffe, J.B. and Brasier, M.D. 2011. Fossils with Little Relief: Using Lasers to Conserve, Image, and Analyze the Ediacara Biota. Quantifying the Evolution of Early Life : Numerical Approaches to the Evaluation of Fossils and Ancient Ecosystems 36: 223-240.

Brasier, M.D., Antcliffe, J.B., and Callow, R.H.T. 2011. Evolutionary Trends in Remarkable Fossil Preservation Across the Ediacaran-Cambrian Transition and the Impact of Metazoan Mixing. In: P.A. Allison, and D.J. Bottjer (eds.), Taphonomy: Process and Bias through Time, Second Edition, 519-567.

Bruton, D.L. and Haas, W. 1997. Functional morphology of Phacopinae (Trilobita) and the mechanics ofenrolment. Palaeontographica Abteilung A: 1-43.

Budd, G.E. 1999. A nektaspid arthropod from the Early Cambrian Sirius Passet fauna, with a description of retrodeformation based on functional morphology. Palaeontology 42 (1): 99-122.

Budd, G.E. 2011. Campanamuta mantonae gen. et. sp. nov., an exceptionally preserved arthropod from the Sirius Passet Fauna (Buen Formation, lower Cambrian, North Greenland). Journal of Systematic Palaeontology 9 (2): 217-260.

Budd, G.E., Butterfield, N.J., and Jensen, S. 2001. Crustaceans and the "Cambrian explosion". Science 294 (5549): U1-U1.

Budil, P., Fatka, O. and Bruthansová, J. 2003. Trilobite fauna of the Šárka Formation at Praha-Červený vrch Hill (Ordovician, Barrandian area, Czech Republic). Bulletin of Geosciences 78 (2): 113-117.

Caron, J.-B. and Jackson, D.A. 2008. Paleoecology of the greater phyllopod bed community, Burgess Shale. Palaeogeography, Palaeoclimatology, Palaeoecology 258 (3): 222-256.

Caron, J.-B., Rudkin, D.M., and Milliken, S. 2004. A new late Silurian (Pridolian) naraoiid (Euarthropoda: Nektaspida) from the Bertie Formation of southern Ontario, Canada-delayed fallout from the Cambrian explosion. Journal of Paleontology 78 (6): 1138-1145. 
430

431

432

433

434

435

436

437

438

439

440

441

442

443

444

445

446

447

448

449

450

451

452

453

454

455

456

457

458

459

460

461

462

463

464

465

466

467

468

469

470

471

472

473

474

475

476

Chen, J.-Y., Edgecombe, G.D., and Ramskold, L. 1997. Morphological and ecological disparity in naraoiids (Arthropoda) from the Early Cambrian Chengjiang fauna, China.

Chen, X., Ortega-Hernández, J., Wolfe, J.M., Zhai, D., Hou, X., Chen, A., Mai, H., and Liu, Y. 2019. The appendicular morphology of Sinoburius lunaris and the evolution of the artiopodan clade Xandarellida (Euarthropoda, early Cambrian) from South China. BMC evolutionary biology 19 (1): 165.

Choubert, G., Termier, H., and Termier, G. 1947. Sur la stratigraphie de l'Ordovicien marocain. Comptes Rendus Sommaire Société Géologique France 16: 335-337.

Corbacho, J. and Vela, A. 2010. Giant Trilobites from Lower Ordovician of Morocco. Batalleria 15: 3-34.

Daley, A.C., Antcliffe, J.B., Drage, H.B., and Pates, S. 2018. Early fossil record of Euarthropoda and the Cambrian Explosion. Proceedings of the National Academy of Sciences 115 (21): 5323-5331.

Destombes, J., Hollard, H., and Willefert, S. 1985. Lower palaeozoic rocks of Morocco. Lower Palaeozoic of north-western and west-central Africa: 91-336.

Dunne, J.A., Williams, R.J., Martinez, N.D., Wood, R.A., and Erwin, D.H. 2008. Compilation and network analyses of Cambrian food webs. PLoS biology 6 (4): e102.

Dzik, J. and Lendzion, K. 1988. The oldest arthropods of the East European Platform. Lethaia 21 (1): 2938.

Edgecombe, G.D. and Ramsköld, L. 1999. Relationships of Cambrian Arachnata and the systematic position of Trilobita. Journal of Paleontology 73 (2): 263-287.

Esteve, J., Hughes, N.C., and Zamora, S. 2013. Thoracic structure and enrolment style in middle Cambrian Eccaparadoxides pradoanus presages caudalization of the derived trilobite trunk. Palaeontology 56 (3): 589-601.

Fortey, R. and Theron, J. 1994. A new Ordovician arthropod, Soomaspis, and the agnostid problem. Palaeontology 37 (4): 841-862.

Fu, D., Tong, G., Dai, T., Liu, W., Yang, Y., Zhang, Y., Cui, L., Li, L., Yun, H., Wu, Y. and Sun, A. 2019. The Qingjiang biota-a burgess shale-type fossil lagerstätte from the early cambrian of South China. Science 363 (6433): 1338-1342.

Gaines, R.R., Hammarlund, E.U., Hou, X., Qi, C., Gabbott, S.E., Zhao, Y., Peng, J., and Canfield, D.E. 2012. Mechanism for Burgess Shale-type preservation. Proceedings of the National Academy of Sciences 109 (14): 5180-5184.

Geyer, G. 1996. The Moroccan fallotaspidid trilobites revisited. Beringeria 18: 89-199.

Gutiérrez-Marco, J.C. and Martin, E.L. 2016. Biostratigraphy and palaeoecology of Lower Ordovician graptolites from the Fezouata Shale (Moroccan Anti-Atlas). Palaeogeography, palaeoclimatology, palaeoecology 460: 35-49.

Gutiérrez-Marco, J.C., García-Bellido, D., Rábano I., and Sá, A.A. 2017. Digestive and appendicular softparts, with behavioural implications, in a large Ordovician trilobite from the Fezouata Lagerstätte, Morocco. Scientific Reports 7: 39728.

Hammann, W., Laske, R., and Pillola, G. 1990. Tariccoia arrusensis ngn sp., an unusual Trilobite-like arthtropod. Rediscovery of the" phyllocarid" bed of Taricco (1922) in the Ordovician" Puddinga" sequence of Sardinia. Bollettino della Societa Paleontologica Italiana 29: 163-178.

Hammann, W. and Leone, F. 1997. Trilobites of the post-Sardic (Upper Ordovician) sequence of southern Sardinia. Part I. Beringeria 20: 3-217.

Harper, D.A., Hammarlund, E.U., Topper, T.P., Nielsen, A.T., Rasmussen, J.A., Park, T.-Y.S., and Smith, M.P. 2019. The Sirius Passet Lagerstätte of North Greenland: a remote window on the Cambrian Explosion. Journal of the Geological Society 176 (6): 1023-1037.

Hou, X. and Bergström, J. 1997. Arthropods of the lower Cambrian Chengjiang fauna, southwest China. Fossils and Strata 45: 1-116. 
Hou, X., Williams, M., Sansom, R., Siveter, D.J., Siveter, D.J., Gabbott, S., Harvey, T.H., Cong, P., and Liu, Y. 2018. A new xandarellid euarthropod from the Cambrian Chengjiang biota, Yunnan Province, China. Geological Magazine 156 (8): 1375-1384.

Ivantsov, A.Y. 1999. Trilobite-like arthropod from the Lower Cambrian of the Siberian Platform. Acta Palaeontologica Polonica 44 (4): 455-466.

Laibl, L., Esteve, J., and Fatka, O. 2016. Enrollment and thoracic morphology in paradoxidid trilobites from the Cambrian of the Czech Republic. Fossil Imprint 72 (3-4): 161-171.

Landing, E., Antcliffe, J.B., Geyer, G., Kouchinsky, A., Bowser, S.S., and Andreas, A. 2018. Early evolution of colonial animals (Ediacaran Evolutionary Radiation-Cambrian Evolutionary Radiation-Great Ordovician Biodiversification Interval). Earth Science Reviews 178: 105-135.

Lefebvre, B., Gutiérrez-Marco, J.C., Lehnert, O., Martin, E.L., Nowak, H., Akodad, M., El Hariri, K., and Servais, T. 2018. Age calibration of the Lower Ordovician Fezouata Lagerstätte, Morocco. Lethaia 51 (2): 296-311.

Legg, D.A., Sutton, M.D., and Edgecombe, G.D. 2013. Arthropod fossil data increase congruence of morphological and molecular phylogenies. Nature communications 4: 2485.

Lehnert, O., Nowak, H., Sarmiento, G.N., Gutiérrez-Marco, J.C., Akodad, M., and Servais, T. 2016. Conodonts from the Lower Ordovician of Morocco-Contributions to age and faunal diversity of the Fezouata Lagerstätte and peri-Gondwana biogeography. Palaeogeography, palaeoclimatology, palaeoecology 460: 50-61.

Lendzion, K. 1975. Fauna of the Mobergella zone in the Polish Lower Cambrian. Geological Quarterly 19 (2): 237-242.

Lerosey-Aubril, R., Gaines, R.R., Hegna, T.A., Ortega-Hernández, J., Van Roy, P., Kier, C., and Bonino, E. 2018. The Weeks Formation Konservat-Lagerstätte and the evolutionary transition of Cambrian marine life. Journal of the Geological Society 175 (5): 705-715.

Lerosey-Aubril, R., Kimmig, J., Pates, S., Skabelund, J., Weug, A. and Ortega-Hernández, J. 2020. New exceptionally preserved panarthropods from the Drumian Wheeler Konservat-Lagerstatten of the House Range of Utah. Papers in Palaeontology in press. doi: 10.1002/spp2.1307.

Lerosey-Aubril, R., Zhu, X., and Ortega-Hernández, J. 2017. The Vicissicaudata revisited-insights from a new aglaspidid arthropod with caudal appendages from the Furongian of China. Scientific reports 7 (1): 11117.

Marshall, C.R. 2006. Explaining the Cambrian "explosion" of animals. Annual Review of Earth and Planetary Sciences 34: 355-384.

Martin, E.L., Pittet, B., Gutiérrez-Marco, J.-C., Vannier, J., El Hariri, K., Lerosey-Aubril, R., Masrour, M., Nowak, H., Servais, T., and Vandenbroucke, T.R. 2015. The Lower Ordovician Fezouata Konservat-Lagerstätte from Morocco: age, environment and evolutionary perspectives. Gondwana Research 34: 274-283.

Martin, E.L., Vidal, M., Vizcaïno, D., Vaucher, R., Sansjofre, P., Lefebvre, B., and Destombes, J. 2016. Biostratigraphic and palaeoenvironmental controls on the trilobite associations from the Lower Ordovician Fezouata Shale of the central Anti-Atlas, Morocco. Palaeogeography, palaeoclimatology, palaeoecology 460: 142-154.

Mayers, B., Aria, C., and Caron, J.B. 2019. Three new naraoiid species from the Burgess Shale, with a morphometric and phylogenetic reinvestigation of Naraoiidae. Palaeontology 62 (1): 19-50.

Nowak, H., Servais, T., Pittet, B., Vaucher, R., Akodad, M., Gaines, R.R., and Vandenbroucke, T.R. 2016. Palynomorphs of the Fezouata Shale (Lower Ordovician, Morocco): age and environmental constraints of the Fezouata Biota. Palaeogeography, palaeoclimatology, palaeoecology 460: 6274. 
Oggiano, G., Martini, I., and Tongiorgi, M. 1986. Sedimentology of the Ordovician" Puddinga" Formation (SW-Sardinia).-IGCP ProjectNo. 5: Correlation of Prevariscan and Variscan events in the AlpineMediterranean mountain belts. Final Meeting, Sardinia, May 25-31, 1986. papers.

Ortega-Hernández, J., Azizi, A., Hearing, T.W., Harvey, T.H., Edgecombe, G.D., Hafid, A., and El Hariri, K. 2017. A xandarellid artiopodan from Morocco-a middle Cambrian link between soft-bodied euarthropod communities in North Africa and South China. Scientific reports 7: 42616.

Ortega-Hernández, J., Esteve, J. and Butterfield, N.J. 2013b. Humble origins for a successful strategy: complete enrolment in early Cambrian olenellid trilobites. Biology letters 9 (5): 20130679.

Ortega-Hernández, J., Legg, D.A., and Braddy, S.J. 2013a. The phylogeny of aglaspidid arthropods and the internal relationships within Artiopoda. Cladistics 29 (1): 15-45.

Paterson, J.R., Edgecombe, G.D., García-Bellido, D.C., Jago, J.B., and Gehling, J.G. 2010. Nektaspid arthropods from the lower Cambrian Emu Bay Shale Lagerstätte, South Australia, with a reassessment of lamellipedian relationships. Palaeontology 53 (2): 377-402.

Paterson, J.R., García-Bellido, D.C., and Edgecombe, G.D. 2012. New Artiopodan Arthropods from the Early Cambrian Emu Bay Shale Konservat-Lagerstätte of South Australia. Journal of Paleontology 86 (2): 340-357.

Paterson, J.R., García-Bellido, D.C., Jago, J.B., Gehling, J.G., Lee, M.S., and Edgecombe, G.D. 2016. The Emu Bay Shale Konservat-Lagerstätte: a view of Cambrian life from East Gondwana. Journal of the Geological Society 173 (1): 1-11.

Peng, S., Babcock, L., and Cooper, R. 2012. The Cambrian Period. The geologic time scale 2: 437-488.

Peters, S.E. and Gaines, R.R. 2012. Formation of the 'Great Unconformity'as a trigger for the Cambrian explosion. Nature 484 (7394): 363.

Repina, L. and Okuneva, O. 1969. Cambrian arthropods of the Maritime Territory. Paleontological Journal 3: 95-103.

Robison, R.A. 1984. New occurrences of the unusual trilobite Naraoia from the Cambrian of Idaho and Utah.

Saleh, F., Antcliffe, J.B., Lefebvre, B., Pittet, B., Laibl, L., Gueriau, P., Perez Peris, F., Lustri, L., and Daley, A.C. 2020. Fossilization bias in exceptionally preserved biotas. Earth and Planetary Science Letters 529: 115873.

Schwimmer, D.R. and Montante, W.M. 2007. Exceptional fossil preservation in the Conasauga Formation, Cambrian, northwestern Georgia, USA. Palaios 22 (4): 360-372.

Scotese, C. 2004. Cenozoic and Mesozoic paleogeography: changing terrestrial biogeographic pathways. Frontiers of biogeography: new directions in the geography of nature: 9-26.

Servais, T. and Harper, D.A. 2018. The great Ordovician biodiversification event (GOBE): definition, concept and duration. Lethaia 51 (2): 151-164.

Servais, T., Owen, A.W., Harper, D.A., Kröger, B., and Munnecke, A. 2010. The great ordovician biodiversification event (GOBE): the palaeoecological dimension. Elsevier.

Theron, J., Rickards, R., and Aldridge, R. 1990. Bedding plane assemblages of Promissum pulchrum, a new giant Ashgill conodont from the Table Mountain Group, South Africa. Palaeontology 33 (3): 577-594.

Torsvik, T.H. and Cocks, L.R.M. 2013a. Gondwana from top to base in space and time. Gondwana Research 24 (3-4): 999-1030.

Torsvik, T.H. and Cocks, L.R.M. 2013b. New global palaeogeographical reconstructions for the Early Palaeozoic and their generation. Geological Society, London, Memoirs 38 (1): 5-24.

Van Roy, P. 2013. Nektaspidid arthropods from the early Ordovician Fezouata Biota, Morocco. 2013 GSA Annual Meeting in Denver.

Van Roy, P., Briggs, D.E., and Gaines, R.R. 2015a. The Fezouata fossils of Morocco; an extraordinary record of marine life in the Early Ordovician. Journal of the Geological Society 172 (5): 541-549. 
Van Roy, P., Daley, A.C., and Briggs, D.E. 2015b. Anomalocaridid trunk limb homology revealed by a giant 572 filter-feeder with paired flaps. Nature 522 (7554): 77.

Van Roy, P., Orr, P.J., Botting, J.P., Muir, L.A., Vinther, J., Lefebvre, B., El Hariri, K., and Briggs, D.E. 2010. Ordovician faunas of Burgess Shale type. Nature 465 (7295): 215.

Vannier, J. and Chen, J.y. 2002. Digestive system and feeding mode in Cambrian naraoiid arthropods. Lethaia 35 (2): 107-120.

Vaucher, R., Martin, E.L., Hormière, H., and Pittet, B. 2016. A genetic link between Konzentrat-and Konservat-Lagerstätten in the Fezouata Shale (lower Ordovician, Morocco). Palaeogeography, palaeoclimatology, palaeoecology 460: 24-34.

Whittington, H.B. 1977. The Middle Cambrian trilobite Naraoia, Burgess Shale, British Columbia. Philosophical Transactions of the Royal Society of London. B, Biological Sciences 280 (974): 409443.

Whittington, H.B. 1985. Tegopelte gigas, a second soft-bodied trilobite from the Burgess Shale, Middle Cambrian, British Columbia. Journal of Paleontology: 1251-1274.

Whittington, H.B. 1989. Olenelloid trilobites: type species, functional morphology and higher classification. Philosophical Transactions of the Royal Society of London. B, Biological Sciences 324 (1221): 111-147.

Zhai, D., Edgecombe, G.D., Bond, A.D., Mai, H., Hou, X. and Liu, Y., 2019. Fine-scale appendage structure of the Cambrian trilobitomorph Naraoia spinosa and its ontogenetic and ecological implications. Proceedings of the Royal Society B, 286 (1916): p.20192371.

Zhang, W.-T. and Hou, X.-G. 1985. Preliminary notes on the occurrence of the unusual trilobite Naraoia in Asia. Acta Palaeontologica Sinica 24 (6): 591-595.

Zhang, X., Ahlberg, P., Babcock, L.E., Choi, D.K., Geyer, G., Gozalo, R., Hollingsworth, J.S., Li, G., Naimark, E.B., and Pegel, T. 2017. Challenges in defining the base of Cambrian Series 2 and Stage 3. EarthScience Reviews 172: 124-139.

Zhang, X., Fu, D., and Dai, T. 2012. A new species of Kangacaris (Arthropoda) from the Chengjiang lagerstätte, lower Cambrian, southwest China. Alcheringa: An Australasian Journal of Palaeontology 36 (1): 23-25.

Zhang, X., Shu, D., Li, Y., and Han, J. 2001. New sites of Chengjiang fossils: crucial windows on the Cambrian explosion. Journal of the Geological Society 158 (2): 211-218.

Zhang, X.-L., Shu, D.-G., and Erwin, D.H. 2007. Cambrian naraoiids (Arthropoda): morphology, ontogeny, systematics, and evolutionary relationships. Journal of Paleontology 81 (sp68): 1-53.

Zhao, F., Caron, J.-B., Hu, S., and Zhu, M. 2009. Quantitative analysis of taphofacies and paleocommunities in the Early Cambrian Chengjiang lagerstatte. Palaios 24 (12): 826-839. 
606

607

608 Figures

609 Figure 1. Tariccoia tazagurtensis sp. nov., Araneograptus murrayi Zone (Tremadocian, Lower 610 Ordovician), Fezouata Shale, near Beni Zouli (Morocco). MGL 102155a, holotype, 611 photographed dry (a), interpretative drawing (b), photographed under ethanol (c). MGL 103036a, 612 photographed dry (d), interpretative drawing (e), photographed under ethanol (f). Abbreviations: 613 ce, cephalic shield; dg, digestive glands; fl, flange; ga, genal angle; mk, median keel; py, 614 pygidium; rd, marginal ridge; rm, marginal rim; T1-T4, thoracic tergite one to four. Scale bar is 1 $615 \mathrm{~mm}$.

616

617 Figure 2. Tariccoia tazagurtensis sp. nov., Araneograptus murrayi Zone (Tremadocian, Lower 618 Ordovician), Fezouata Shale, near Beni Zouli (Morocco); close-up of the anterior part of the 619 cephalic shield of the holotype, MGL 102155a (a) and of MGL 103036a (b). Arrows pointing to 620 proximal parts of digestive glands (a), and to bifurcation of digestive glands (b). Scale bar is 1 $621 \mathrm{~mm}$.

622

623 Figure 3. Reconstruction of members of the family Liwiidae Dzik \& Lendzion, 1988 and the 624 genus Buenaspis Budd, 1999: (a) Tariccoia tazagurtensis sp. nov., Fezouata Shale, Morocco; (b) 625 Tariccoia arrusensis Hammann et al., 1990, Riu is Arrus Member of the Monte Argentu 626 Formation, Sardinia; (c) Liwia plana (Lendzion, 1975), Zawiszyn Formation, Poland; (d) 627 Soomaspis splendida Fortey \& Theron, 1994, Soom Shale, South Africa; (e) Buenaspis forteyi 
628 Budd, 1999, Buen Formation, Greenland. Dotted lines represent underlying structures of the 629 dorsal exoskeleton. Scale bar is $1 \mathrm{~mm}$. Reconstruction of T. arrusensis, L. plana, S. splendida 630 and B. fortey based on Hammann et al. (1990), personal observation, Fortey and Theron (1994), 631 and Budd (1999), respectively.

632

633 Figure 4. Paleogeographical distribution of nektaspids during the Cambrian (a), Ordovician and 634 Silurian (b) periods. Map reconstruction for the early Cambrian (520 Ma) (a) and Early 635 Ordovician, Tremadocian (480 Ma) (b); redrawn, adapted and simplified from Torsvik \& Cocks 636 (2013a, fig. 2.7 and fig. 2.11). The Silurian species Naraoia bertensis Caron et al. 2004, is 637 marked by asterisk. Distribution data based on Whittington 1977, Robison 1984, Dzik and 638 Lendzion 1988, Hammann et al. 1990, Fortey and Theron 1994, Hou and Bergström 1997, Chen 639 et al. 1997, Budd 1999, Budil et al. 2003, Caron et al. 2004, Schwimmer and Montante 2007, 640 Zhang et al. 2007, Paterson et al. 2010, Peng et al. 2012, Zhang et al. 2012, Fu et al. 2019, 641 Mayers et al. 2019, Lerosey-Aubril et al. 2020. 

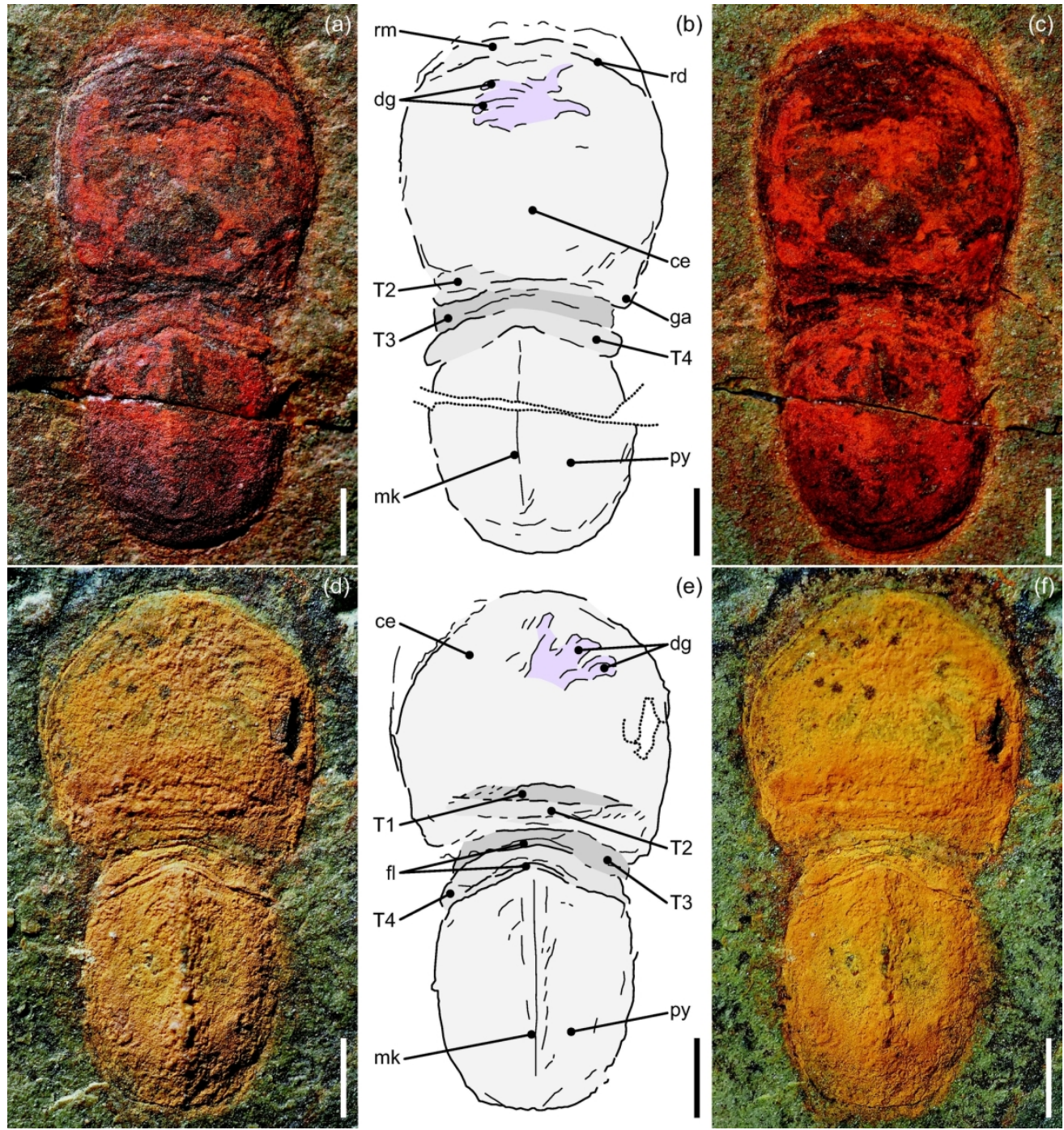

(e)

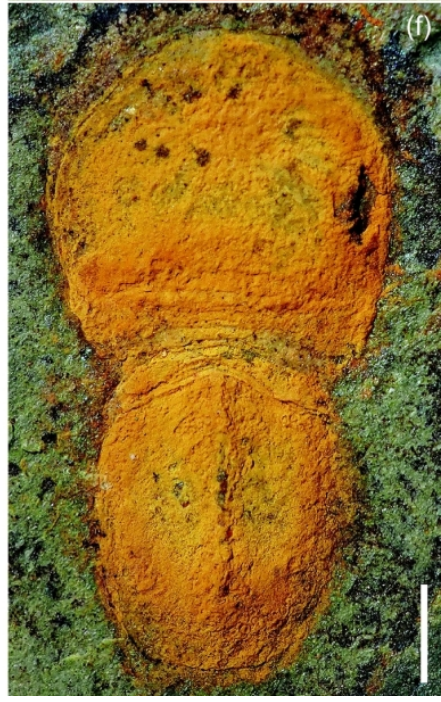

Figure 1. Tariccoia tazagurtensis sp. nov., Araneograptus murrayi Zone (Tremadocian, Lower Ordovician), Fezouata Shale, near Beni Zouli (Morocco). MGL 102155a, holotype, photographed dry (a), interpretative drawing (b), photographed under ethanol (c). MGL 103036a, photographed dry (d), interpretative drawing (e), photographed under ethanol (f). Abbreviations: ce, cephalic shield; dg, digestive glands; fl, flange; ga, genal angle; mk, median keel; py, pygidium; rd, marginal ridge; rm, marginal rim; T1-T4, thoracic tergite one to four. Scale bar is $1 \mathrm{~mm}$.

$168 \times 180 \mathrm{~mm}(300 \times 300 \mathrm{DPI})$ 


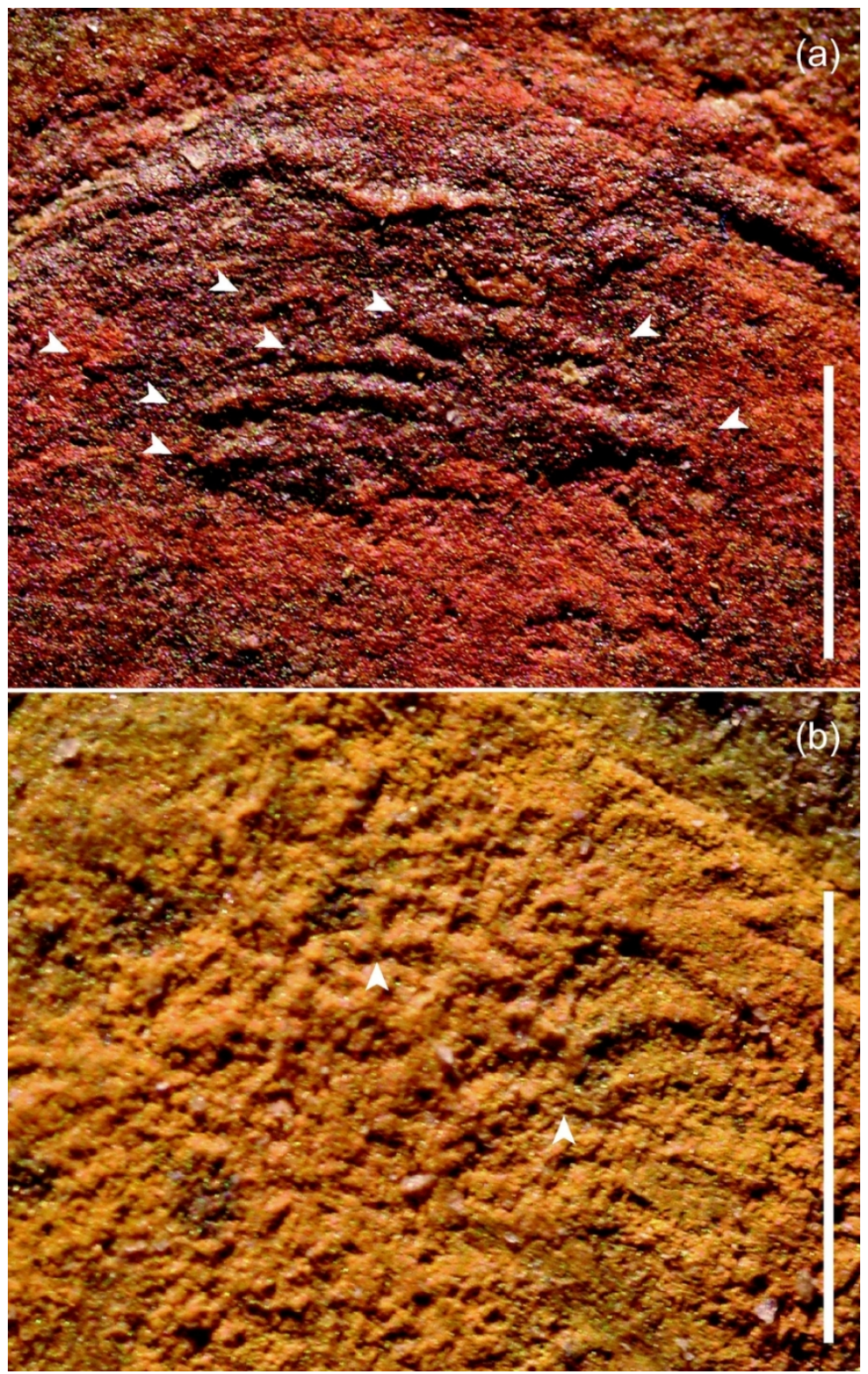

Figure 2. Tariccoia tazagurtensis sp. nov., Araneograptus murrayi Zone (Tremadocian, Lower Ordovician), Fezouata Shale, near Beni Zouli (Morocco); close-up of the anterior part of the cephalic shield of the holotype, MGL 102155a (a) and of MGL 103036a (b). Arrows pointing to proximal parts of digestive glands (a), and to bifurcation of digestive glands (b). Scale bar is $1 \mathrm{~mm}$.

\author{
$80 \times 128 \mathrm{~mm}(300 \times 300$ DPI $)$
}


(a)

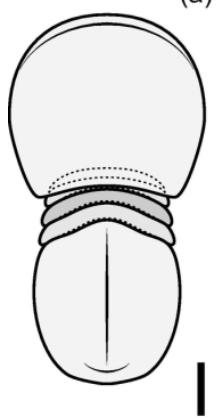

(b)

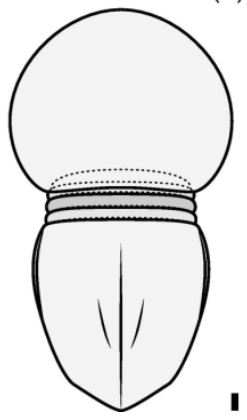

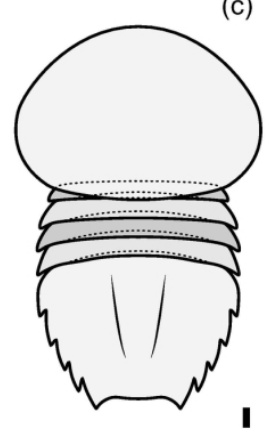

(c)

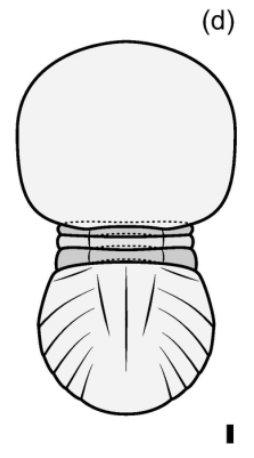

(d)

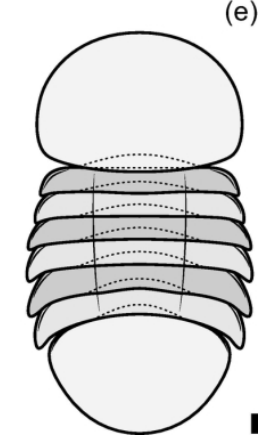

Figure 3. Reconstruction of members of the family Liwiidae Dzik \& Lendzion, 1988 and the genus Buenaspis Budd, 1999: (a) Tariccoia tazagurtensis sp. nov., Fezouata Shale, Morocco; (b) Tariccoia arrusensis Hammann et al., 1990, Riu is Arrus Member of the Monte Argentu Formation, Sardinia; (c) Liwia plana (Lendzion, 1975), Zawiszyn Formation, Poland; (d) Soomaspis splendida Fortey \& Theron, 1994, Soom Shale, South Africa; (e) Buenaspis forteyi Budd, 1999, Buen Formation, Greenland. Dotted lines represent underlying structures of the dorsal exoskeleton. Scale bar is $1 \mathrm{~mm}$. Reconstruction of $T$. arrusensis, L. plana,

S. splendida and B. fortey based on Hammann et al. (1990), personal observation, Fortey and Theron (1994), and Budd (1999), respectively.

$169 \times 57 \mathrm{~mm}(300 \times 300 \mathrm{DPI})$ 


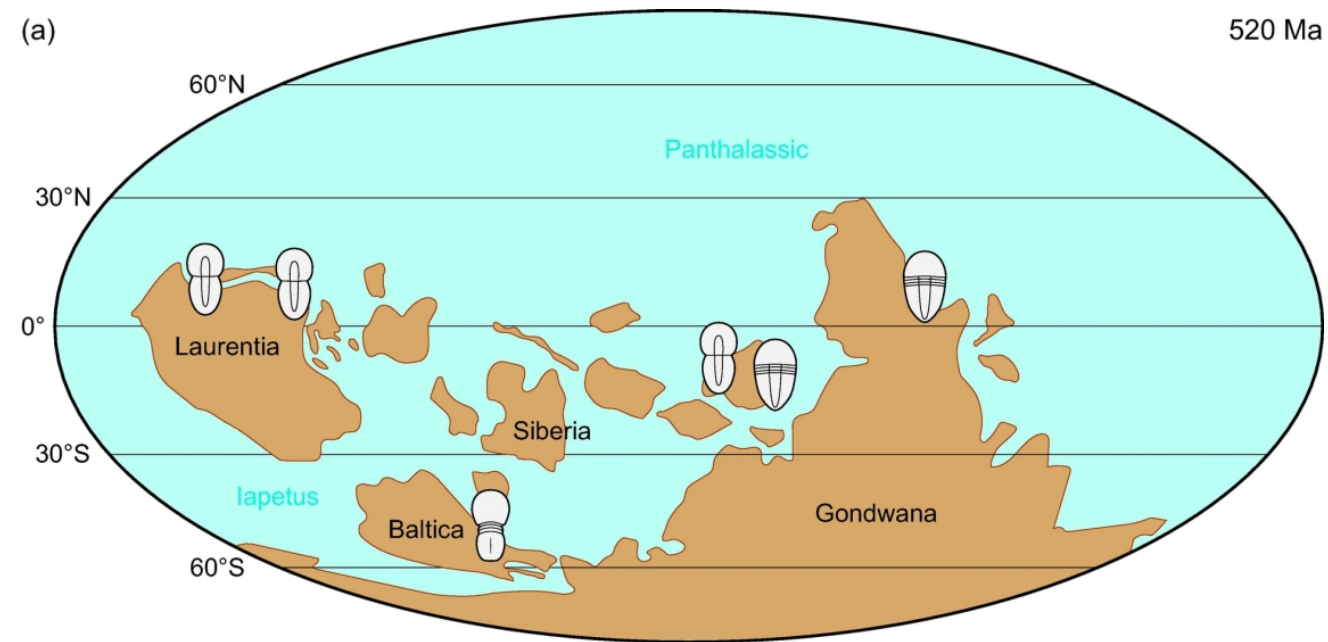

(b)

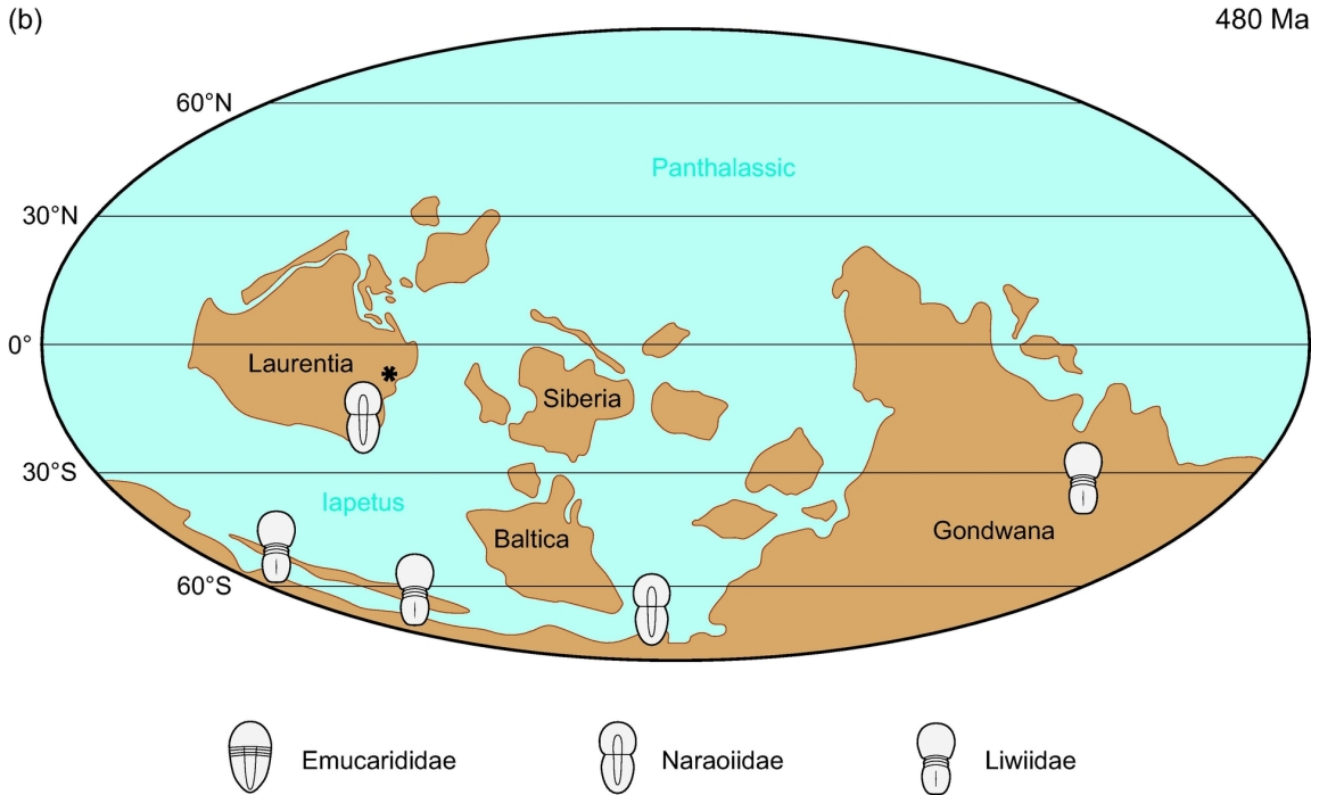

Figure 4. Paleogeographical distribution of nektaspids during the Cambrian (a), Ordovician and Silurian (b) periods. Map reconstruction for the early Cambrian (520 Ma) (a) and Early Ordovician, Tremadocian (480 Ma) (b); redrawn, adapted and simplified from Torsvik \& Cocks (2013a, fig. 2.7 and fig. 2.11). The Silurian species Naraoia bertensis Caron et al. 2004, is marked by asterisk. Distribution data based on Whittington 1977, Robison 1984, Dzik and Lendzion 1988, Hammann et al. 1990, Fortey and Theron 1994, Hou and Bergström 1997, Chen et al. 1997, Budd 1999, Budil et al. 2003, Caron et al. 2004, Schwimmer and Montante 2007, Zhang et al. 2007, Paterson et al. 2010, Peng et al. 2012, Zhang et al. 2012, Fu et al. 2019, Mayers et al. 2019, Lerosey-Aubril et al. 2020. 